\title{
Enhancing Interpersonal Competencies Of Business-College Students
}

Louis Miller, (E-mail: louisnash@comcast.net), Tennessee State University

\begin{abstract}
Business schools quite properly emphasize quantitative techniques, but neglect training in businessrelevant interpersonal competencies. Increased use of experiential learning technology is proposed as a partial remedy.
\end{abstract}

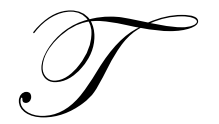

here is a widespread and growing dissatisfaction with the educational results of current businesscollege curricula. The complaints being registered refer to undergraduate programs as well as graduate-level training, although the latter have been more prominent, presumably because of the higher costs incurred by students in obtaining a graduate-level degree and the greater risks and costs incurred by corporations in hiring MBAs. In-depth reviews of the value of a business-school education at either level are consistent in their general complaint: there seems to be little relation between the curriculum covered in business schools and later business success. For example, Pfeffer and Fong (2002), after reviewing a long series of relevant empirical studies, conclude that "There is little evidence that mastery of the knowledge acquired in business schools enhances people's careers, or that even attaining the MBA credential itself has much effect on graduates' salaries or career attainment."

Complaints about business-college programs revolve around three main themes: (1) the focus of the subject matter in the typical curriculum; (2) the teaching methodologies being employed; and (3) the focus and quality of management research being produced. This presentation seeks to respond constructively to the first two complaints.

With regard to the first theme, course content, Jenkins and Reizenstein (1984), referring to a 1982 survey conducted by the Graduate Management Admissions Council, reported "perceived weakness in personal skills" as a major recurring theme expressed by respondents. Porter and McKibbin (1988) reported that critics of the businessschool curriculum felt that quantitative analytic techniques, though important, were being overemphasized while insufficient attention was being given to developing leadership and interpersonal skills. Mintzberg (1996) has been among the most severe of the critics of the business-school curriculum content; he and his colleagues (e.g., Mintzberg and Gosling, 2002) have repeatedly bemoaned the lack of adequate training in the interpersonal skills required in the practice of managing. The same complaint keeps recurring. A report issued by the Management Education Task Force of the Association to Advance Collegiate Schools of Business (2002) expressed concern about the adequacy of current business-school curricula in providing training in the kinds of managerial skills and competencies needed in the twenty-first century global business environment. The AACSB's recommendations stressed the need for increased training in "communication, interpersonal skills, multicultural skills, negotiation, leadership development, and change management." Doria, Rozanski, and Cohen (2003) list as their first principle for MBA program reform: business schools should require more courses in the "people skills" that are vital to managing effectively.

Dissatisfaction with the current focus of the typical business-school curriculum content continues to mount. The issue appears to be important enough to receive attention by the most highly regarded luminaries publishing in the most prestigious journals devoted to business practice. For example, Warren Bennis and James O'Toole, in the current issue of the Harvard Business Review (Bennis and O'Toole, 2005), echoing the same criticisms rendered repeatedly over the past twenty-five years, provide an explanation of historical causality underlying the ongoing malaise and propose that what is called for is a major restoration of balance in curricular content. Exemplifying the gist of their main argument, they quote Thomas Lindsay, former Provost of the University of Dallas: 
(B)usiness education in this country is devoted overwhelmingly to technical training. This is ironic, because even before Enron, studies showed that executives who fail - financially as well as morally - rarely do so from a lack of expertise. Rather, they fail because they lack interpersonal skills and practical wisdom...

With regard to the second theme, teaching methodology, Doria, Rozanski, and Cohen (2003) sum up the current situation nicely: ". . . most graduate programs still focus on traditional lecture and case discussion ..." The situation, however, is rather ironic: the need, so clearly articulated and widely expressed, for enhancement of interpersonal competencies of business students, is precisely the need that cannot be satisfied by the traditional approach to management education. A different teaching technology is mandatory.

There is a remarkable concurrence of informed opinion as to what that teaching technology must entail. Schon (1987), Leavitt (1989), Bailey and Ford (1996), Mintzberg and Lampel (2001), and numerous other luminaries addressing the challenge of improving management education all agree that, in one form or another, improvement must entail experiential learning on the part of business students. Corporations complain that their MBA hirees can accurately quote eight different theories of motivation but do not know how to motivate their own subordinates. As Pfeffer and Sutton (2000) point out, learning about is not the same as learning how to!

The majority of advice with respect to inclusion of more experiential learning in the business school curriculum involves setting up some kind of a supervised practicum or internship wherein the business student can gain some "real world" experience. However, as Pfeffer and Fong (2002) point out, taking such a course of action is likely to impose innumerable difficulties for the program administrator. Pfeffer and Fong, after reviewing some of the more serious obstacles to fundamentally altering MBA programs, conclude that "the likelihood of profound change or reform in contemporary management education, at least in the United States and at least as practiced by universitybased business schools, seems limited." They feel unable to justify holding any reasonable expectation that the prevailing inertia can be overcome. Bennis and O'Toole (2005) are also not optimistic about overcoming the entrenched resistance by both deans and faculty to any significant change in the narrow, discipline-focused orientation of current curricula.

However, as an immediate alternative to the difficult task of setting up internships or practica, there exists an alternative form of experiential learning that can be incorporated into existing course structures without requiring any radical modification of the overall academic program. This form consists of very specific experiential exercises designed to improve very specific personal and interpersonal competencies. A large pool of such exercises is available. For the most comprehensive collection of exercises, and guidance in the administration of these exercises, see the ongoing Pfeiffer annual volumes (Pfeiffer, 1972/2005).

The first step in implementing the use of these focused experiential exercises would be for a student, with faculty guidance, and roughly following a self-directed learning model developed by Boyatzis and others (see Boyatzis, 1999), to select a small set of personal/interpersonal competencies the improvement of which would constitute a student's learning objective. Several sets of relevant competencies which could serve as target areas for improvement are available. Napolitano and Henderson (1998) put together a set of 27 competencies and 7 personal attributes that they believe are associated with effective modern leadership. Miller (1999) formulated a set of 32 requisite managerial competencies derived from business conditions expected to prevail early in the twenty-first century. Goleman and his colleagues, in their model of emotional intelligence, prescribe specific personal and interpersonal competencies as target areas for self-improvement (Goleman, Boyatzis, and McKee, 2002). Goleman and his colleagues also provide ample evidence that improvement in the kinds of interpersonal skills addressed by using focused experiential learning technology is both achievable and measurable. Administration of many of the experiential exercises aimed at improving these competencies can be incorporated (with very little juggling) into the traditional format of courses such as Organizational Behavior or Leadership or even Accounting with little or no disturbance of the existing overall school program.

Experiential learning technology is not new. It has been around for some time and is already in use in some quarters, as Bennis and O'Toole report. However, the extent of its use is actually so sparse and the need for what this technology has to offer is so great that a renewed call for increase in its use is warranted. 
Of course, incorporation of focused experiential exercises into business-college teaching methodology is not the complete answer to the challenge of enhancing students' interpersonal competencies. However, it is a step in the right direction, a doable move worth considering when a more ambitious move, e.g., toward a program such as the MBA program at Case Western Reserve's Weatherhead School of Management, is not feasible. It is a more modest move, designed to address an increasingly acknowledged glaring deficiency in our business-college programs.

\section{REFERENCES}

1. Association to Advance Collegiate Schools of Business. (2002). Management Education at Risk: A Report from the Management Education Task Force. April. www.aacsb.edu/metf

2. Bailey, J. \& Ford, C. (1996). Management as science versus management as practice in post-graduate business education. Business Strategy Review, 7(4): 7-12.

3. Bennis, W. G. \& O’Toole, J. (2005). How business schools lost their way. Harvard Business Review, May, 83(5): 96-104.

4. Boyatzis, R. E. (1999). Self-Directed Change and Learning as a Necessary Meta-Competency for Success and Effectiveness in the $21^{\text {st }}$ Century. In Sims, R. and Veres, J. G. (Eds.) Keys to Employee Success in the Coming Decades. Westport, CT: Greenwood Publishing.

5. Doria, J., Rozanski, H., \& Cohen, E. (2003). What business needs from business schools. Strategy + Business, 32(1): 38-45.

6. Goleman, D., Boyatzis, R., \& McKee, A. (2002). Primal Leadership: Realizing the Power of Emotional Intelligence. Boston: Harvard Business School Press.

7. Jenkins, R. L. \& Reizenstein, R. C. (1984). Insights into the MBA: Its contents, output, and relevance. Selections, 2: 19-24.

8. Leavitt, H. J. (1989). Educating our MBAs: On teaching what we haven't taught. California Management Review, 31(3): 38-50.

9. Miller, L. (1999). Requisite competencies of the twenty-first century manager. In Carr, L., Miller, L., and Tucker, B. (Eds.) Readings in human resource management: Adding strategic value to the organization. Acton, MA: Copley.

10. Mintzberg, H. (1996). Ten ideas designed to rile everyone who cares about management. Harvard Business Review, July-August, 61-68.

11. Mintzberg, H. \& Gosling, J. R. (2002). Reality programming for MBAs. Strategy + Business, 26(1): 28-31.

12. Mintzberg, H. \& Lampel, J. (2001). Matter of degrees: Do MBAs make better CEOs? Fortune, February, 19: 244.

13. Napolitano, C. S. \& Henderson, L. J. (1998). The leadership odyssey: A self-development guide to new skills for new times. San Francisco: Jossey-Bass.

14. Pfeffer, J. \& Fong, C. T. (2002). The end of business schools? Less success than meets the eye. Academy of Management Learning and Education, 1: 1.

15. Pfeffer, J. \& Sutton, R. I. (2000). The knowing-doing gap. Boston: Harvard Business School Press.

16. Pfeiffer, J. W. (Ed.) (1972/2005). Human Resource Development Annual. San Francisco: Jossey-Bass.

17. Porter, L. W. \& McKibbin, L. E. (1988). Management education and development: Drift or thrust into the $21^{\text {st }}$ century. New York: McGraw-Hill.

18. Schon, D. (1987). Educating the reflective practitioner. San Francisco: Jossey-Bass. 


\section{NOTES}

